\title{
Exosomes of Adipose-derived Stem Cells Conditioned Media Promotes Retinoblastoma and Forkhead-Box M1 Protein Expression
}

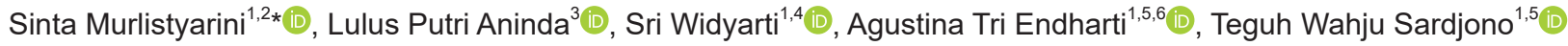 \\ ${ }^{1}$ Doctoral Program of Medical Science, Faculty of Medicine, Universitas Brawijaya, Malang, Indonesia; ${ }^{2}$ Department of \\ Dermatology and Venereology, Faculty of Medicine, Universitas Brawijaya, Malang, Indonesia; ${ }^{3}$ Faculty of Medicine, Universitas \\ Brawijaya, Malang, Indonesia; ${ }^{4}$ Department of Biology, Faculty of Mathematics and Natural Science, Universitas Brawijaya, \\ Malang, Indonesia; ${ }^{5}$ Department of Parasitology, Faculty of Medicine, Universitas Brawijaya, Malang, Indonesia; ${ }^{6}$ Master \\ Program in Biomedical Sciences, Faculty of Medicine, Universitas Brawijaya, Malang, Indonesia
}

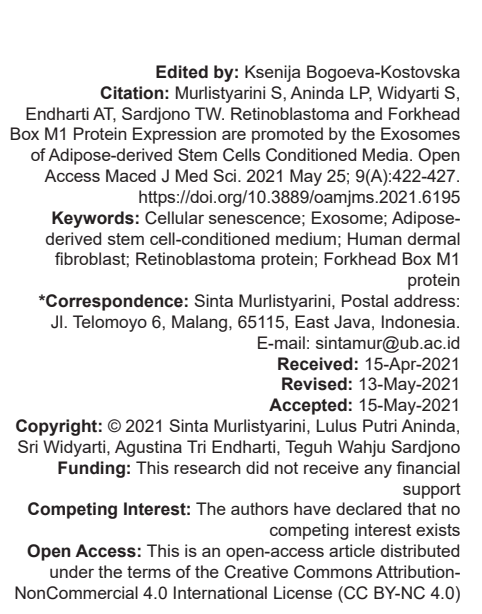

\section{Abstract}

BACKGROUND: In the senescence process, the retinoblastoma $(\mathrm{Rb})$ protein binds to $\mathrm{E} 2 \mathrm{~F}$ in hypophosphorylated conditions, preventing the cell to enter the S-phase in the cell cycle. Human Forkhead Box M1 (FOXM1) protein, key regulator $\mathrm{G} 1 / \mathrm{S}$ and $\mathrm{G} 2 / \mathrm{M}$ phases, decreases in the senescence process. Many studies have been carried out to reverse this system, one of which used exosomes of adipose-derived stem c ells conditioned media (ADSC-CM). These exosomes contain a variety of specific proteins which have pro-proliferation properties, however, little is known on the role of these exosomes toward the change of phosphorylated Rb and FOXM1.

AIM: This study aims to find out the involvement of exosomes of ADSC-CM on these two proteins on senescence human dermal fibroblasts (HDFs).

METHODS: In vitro experiment was undergone randomization sample and non-blinded pre-/post-test control group. The primary culture of senescent HDFs was transfected with exosomes of ADSC-CM; then, its effect on migration and senescence reversal was observed through analyzing Sa- $\beta$-gal, Rb, and FOXM1 protein expression.

RESULTS: The expression of Sa- $\beta$-gal was higher in the control group. Our result demonstrated the exosome of ADSC-CM significantly induced the expression of Rb and FOXM1 protein in senescent HDFs $(p<0.05)$.

CONCLUSION: It proved that exosomes of ADSC-CM could shift the senescent fibroblast into metabolically active cells.

\section{Introduction}

The cell cycle on eukaryotic cells consists of two main phases, mitosis (M) phase and interphase (G1, S, and G2) [1]. The whole-cell cycle progression is coordinated by cyclin-dependent kinases (CDKs) and cyclin protein that work synergistically [2], [3]. G1/S phase transition involves CDK4/6-cyclin D complex and the S phase includes CKD2-cyclin E complex [4], [5], [6]. At the end of the $S$ phase, there will be Forkhead Box M1 (FOXM1) transcription factor involvement [7], [8].

The most critical target of active CDK4/6cyclin $D$ complex is retinoblastoma $(R b)$ protein. Unphosphorylated Rb will interact with unphosphorylated E2F1. However, phosphorylated $\mathrm{Rb}$ will activate the CDK4/6-cyclin D complex that will release E2F1. Once the threshold level of $\mathrm{Rb}$ phosphorylation is reached, E2F1 can promote cells to go to the S phase [9], [10]. Human FOXM1 protein is correlated with pro-proliferative cells and only expressed on proliferative cells, thus, there will be no expression of FOXM1 in quiescence or differentiated cells [11], [12], [13].

Cellular senescence can be defined as a condition when cells leave the cell cycle because of limited proliferation capacity from the culture of human dermal fibroblasts (HDFs). Cells will quit from the cell cycle when one of the pathways is activated, for example, $\mathrm{Rb} / \mathrm{p} 16^{\mathrm{INK} 4 \mathrm{a}}[14]$. Senescent cells can be still alive and metabolically active, but they cannot undergo cell division. Hitherto, senescence is considered as a static end condition. However, recent studies support that senescence is a dynamic multistep process. Cellular senescence could act as a potential tumor suppressor, in contrast, it also improves cancer growth [15]. The senescence initiation happens when cell cycle arrest in which CDK4/6-cyclin $D$ is inhibited by $\mathrm{Rb} / \mathrm{p} 16^{\mathrm{INK} 4 \mathrm{a}}[16]$.

Adipose-derived stem cells conditioned media (ADSC-CM) is potential to solve the aging problem since 
they have low oncogenic potential, ability to secrete cytokine, and other growth factors [17], [18], [19], [20]. The paracrine mechanism secreted by stem cells is caused by the exosome. Exosomes from stem cells including ADSCs give a good prognosis toward tissue repair. However, the molecular mechanisms of ADSCCM-derived exosomes remain unclear. A recent study proved that these exosomes may reverse senescent fibroblasts into normal [21]. In our study, we found that exosomes of ADSC-CM induced both cell migration and reversed cellular senescence by increasing the expression of $\mathrm{Rb}$ and FOXM1.

\section{Materials and Methods}

\section{Adipose-derived stem cells culture}

Adipose-derived stem cells were isolated from subcutaneous adipose tissue during elective cesarean operation from a 25-year-old pregnant woman. Informed consent for sampling and research was attained from the donor. The procedure was approved by the Ethics Committee of Faculty of Medicine, Universitas Brawijaya, Malang, Indonesia (No.169/EC/KEPK-S3/05/2019). Briefly, fat tissue was washed with PBS 3 times. Subsequently, the tissue was filtered on a sieve, then digested in $0.075 \%$ collagenase type I for $30 \mathrm{~min}$ at $37^{\circ} \mathrm{C}$. The homogenate was centrifuged at $1500 \mathrm{rpm}$ for $7 \mathrm{~min}$ to get the pellet and seeded. Adhered cells were cultured and cultivated in high glucose DMEM supplemented with $10 \%$ fetal bovine serum (FBS) at $37^{\circ} \mathrm{C}$ and incubated in a humidified incubator with $5 \% \mathrm{CO}_{2}$. The cells were passaged repeatedly after reaching $70-90 \%$ density. After passage 3-5, the media were changed into serumfree medium and were incubated until $48 \mathrm{~h}$.

\section{Conditioned medium (CM), Exosome, and RNA isolation}

The exosomes were purified from ADSC-CM the growth medium that had been used by ADSCs. The purification of concentrated $\mathrm{CM}$ was using Exosome Purification and RNA Isolation $\mathrm{Kit}^{\circledR}$ (Norgen Biotek, ON, Canada) according to the manufacturer's procedure. The exosomes were characterized by scanning electron microscope (Hitachi Ltd., Japan) and PKH26 Red Fluorescence Cell Linker Kit ${ }^{\circledR}$ (Merck Ltd., Germany).

\section{Fibroblast primary culture}

HDFs were explant culture from human skin. Shortly, the skin was cut into pieces and placed in the 6 -well plate until the explant stick into the plate. Then, the media were added. The cells were expanded in DMEM supplemented with $20 \% \mathrm{FBS}$ at $37^{\circ} \mathrm{C}, 5 \% \mathrm{CO}_{2}$.

\section{Flow cytometry analysis}

ADSCs from passage three to five and adipocytes were trypsinized and followed by intracellular staining. Briefly, the cells were suspended in binding buffer, then the cells were incubated with a monoclonal antibody against CD34 (343616, Norgen Biotek, ON, Canada) and CD44 (338804, Norgen Biotek, ON, Canada) in the dark for $30 \mathrm{~min}$ at $4^{\circ} \mathrm{C}$. The stained cells were washed with cell staining buffer and immediately analyzed using the FACSCalibur flow cytometer and CellQuest Pro software ${ }^{\circledR}$ (BD Bioscience, USA).

\section{Transfection of ADSC-derived exosome and PKH26 staining}

Fibroblasts were plated in a 6-well plate and starved for 3 days to get senescence cells. We used $1 \mu \mathrm{g} / \mathrm{ml}$ exosomes of ADSC-CM. On the day of transfection, the control group was measured for the senescence cells by senescence-associated $\beta$-galactosidase (SA- $\beta$-GAL) assay. While the treated group, the exosomes were stained with red fluorescent PKH26 (Sigma-Aldrich) and added directly into the cell culture media in the plate. Then, they were incubated for $72 \mathrm{~h}$. The cells were collected and counterstained with $1 \mu \mathrm{g} / \mathrm{ml}$ 4',6-diamidino-2-phenylindole (DAPI) solution for an additional $5 \mathrm{~min}$. The detection of the transfection was using an IX71 fluorescence microscope (Olympus).

\section{Sa- $\beta$-gal assay}

Fibroblasts were seeded in a 6-well plate, fixed with $25 \%$ glutaraldehyde for $5 \mathrm{~min}$, and stained overnight in a mixture of cell staining solution from a commercial kit (BioVision). Every group was replicated in triplicate. Images were obtained at $200 \times$ using an IX71 inverted microscope (Olympus).

\section{Scratch assays}

HDFs were seeded in 24-well plates and grown to confluence. When they are confluence, the cells were mechanically wounded with a sterile $200 \mu \mathrm{l}$ pipette tip. After the disruption, remove the debris and smooth the edge of the scratch by washing the cells once with $1 \mathrm{ml}$ of the growth medium and then replace with $5 \mathrm{ml}$ of the medium, and then, the HDFs were incubated in $1 \mu \mathrm{g} / \mathrm{ml}$ exosomes of ADSC-CM for $24 \mathrm{~h}$.

\section{ELISA}

The measurement of Rb1 and FOXM1 protein levels was using Human Rb1 ELISA kit ${ }^{\Theta}$ (MyBioSource) and Human FOXM1 ELISA kit $^{\circledR}$ (MyBioSource), respectively, according to the manufacturer's instructions. Next, we analyzed the data using SPSS statistic software version 25 , while the normality test 
was utilizing the Shapiro-Wilk test. The t-independent test would have been done if $p>0.05$, however, if the data did not meet the requirement, Mann-Whitney U-test would be used.

\section{Results}

\section{The identification of ADSCs}

We observed that ADSCs started to grow and migrate around the explant after 10 days (Figure 1a). The cells were characterized by CD34 as a cell surface marker and have a positive expression of mesenchymal markers (CD44). Aimed to confirm the protein expression at the surface of the ADSCs, we analyzed CD34 and CD44 by a sensitive flow cytometer. The results proved that ADSC cells expressed CD34 and

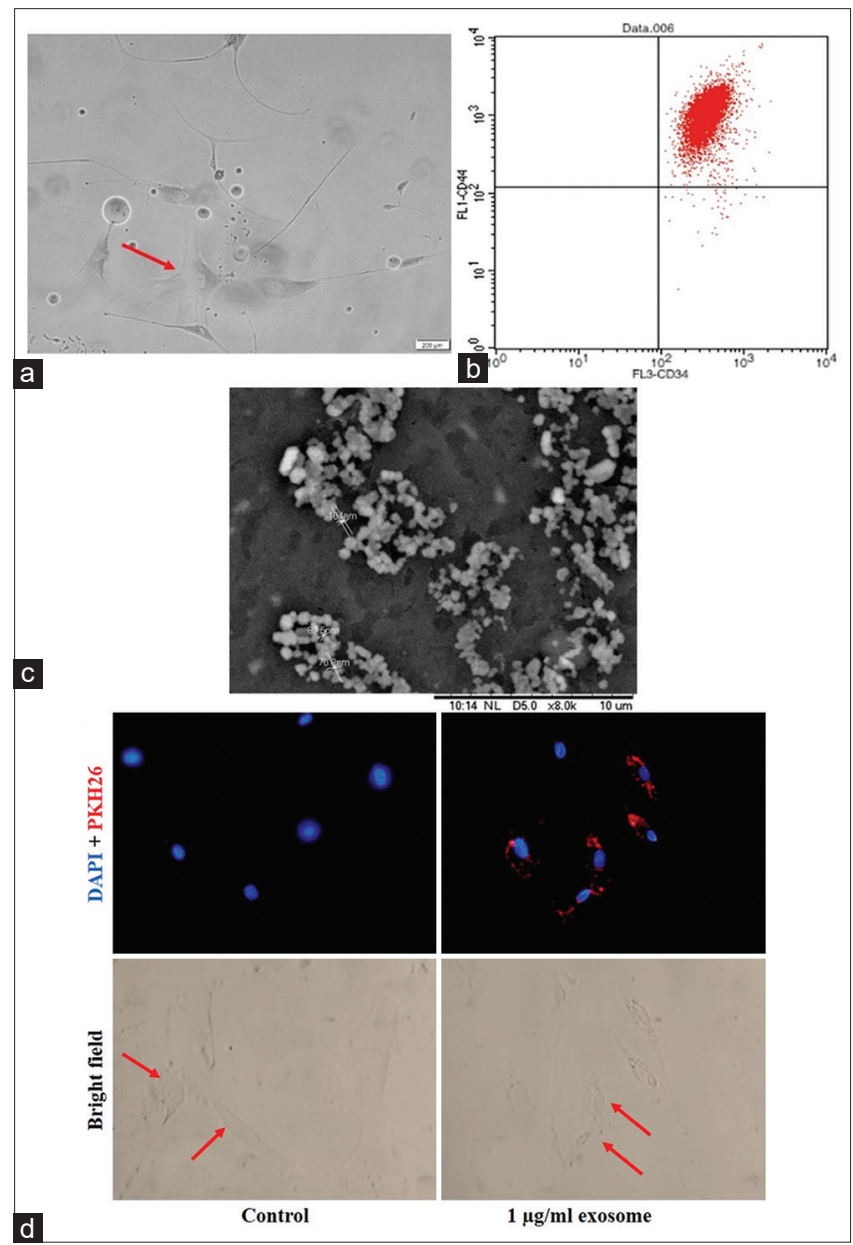

Figure 1: Adipose-derived stem cells (ADSCS) characteristics. Phase contrast micrographs of ADSCs in which one of the ADSCs was pointed by the red arrow (a). CD34 and CD44 that were detected as red dots were measured by a flow cytometer (b). A transmission electron microscope (TEM) was used to identify the presence of ADSC-derived exosome (c). (d) PKH26 staining confirmed that the exosomes were absorbed by human dermal fibroblasts
CD44 (Figure 1b). To prove the existence of exosomes of ADSC-CM, we analyzed them by scanning electron microscopy and the results are shown in light gray color (Figure 1c). Moreover, to confirm that the uptake of exosomes has been successful, we stained the exosomes with $\mathrm{PKH} 26$ and observed them under a fluorescence microscope. The results demonstrated that the HDFs could absorb the exosome (Figure 1d). The red and blue colors in Figure 1d represent exosome and nucleus, respectively. Exosomes were labeled with $\mathrm{PKH} 26$ and DAPI was used to stain the cell nuclei.

\section{Exosomes of ADSC-CM induce migration and reverse senescence activity of HDFs}

To investigate the effect of exosomes of ADSC-CM on the migration of HDFs by scratch assay, we transfected the exosome into HDFs by $72 \mathrm{~h}$ incubation. The result delineated that the transfected HDFs had a higher gap filling area compared to the control group. It suggests that exosomes of ADSC-CM promoted the migration of HDFs (Figure 2a).

Next, we asked whether exosomes ofADSC-CM can shift a senescence HDFs into a normal one. We used Sa- $\beta$-gal assay for several repetitions. This enzyme is a biomarker expressed by senescence fibroblasts [21]. This enzyme is encoded by the GLB1 gene and based on the elevation of the lysosome in senescence cells which enable lysosomal $\beta$-D-galactosidase detection at suboptimal $\mathrm{pH}(\mathrm{pH}$ 6.0) [22], [23], [24]. The result delineates that Sa- $\beta$-gal expression in the control group had a higher number of senescence cells than the exosome-treated group. In the exosome-treated group, the number of senescent HDFs was reduced as indicated in Figure 2b-c. It seems like exosomes of ADSC-CM reverse senescence cells into normal ones.

\section{Rb1 and FOXM1 protein expression in HDFs after being incubated in exosomes of ADSC-CM}

To investigate which mechanism the exosomes of ADSC-CM reverse senescent activity, we used ELISA to determine Rb1 protein expression in HDFs. Our results demonstrate that the average and median of $\mathrm{Rb}$ protein expression in the control group were $0.04 \pm 0.01$ and $0.03 \pm 0.01$, respectively. Identically, the average of the exosome-treated group $(1 \mu \mathrm{g} / \mathrm{ml})$ was $0.07 \pm 0.03$, and the median was $0.06 \pm 0.03$. The results of the normality assumption test for the control group were fulfilled $(p>0.05)$ and the exosome-treated group $(1 \mu \mathrm{g} / \mathrm{ml})$ was not fulfilled $(p<0.05)$. Thus, the MannWhitney hypothesis test was carried out (Table 1).

Table 1: The statistical results of $\mathbf{R b}$ protein expression using Mann-Whitney analyses

\begin{tabular}{lll}
\hline Groups & Average \pm SD $^{*}$ & p-value \\
\hline Control group (untransfected) & $0.04 \pm 0.01$ & $<0.001$ \\
Exosome-treated group $(1 \mu \mathrm{g} / \mathrm{ml}$ exosome) & $0.07 \pm 0.03$ & \\
\hline${ }^{*}$ SD: Standard deviation. & &
\end{tabular}




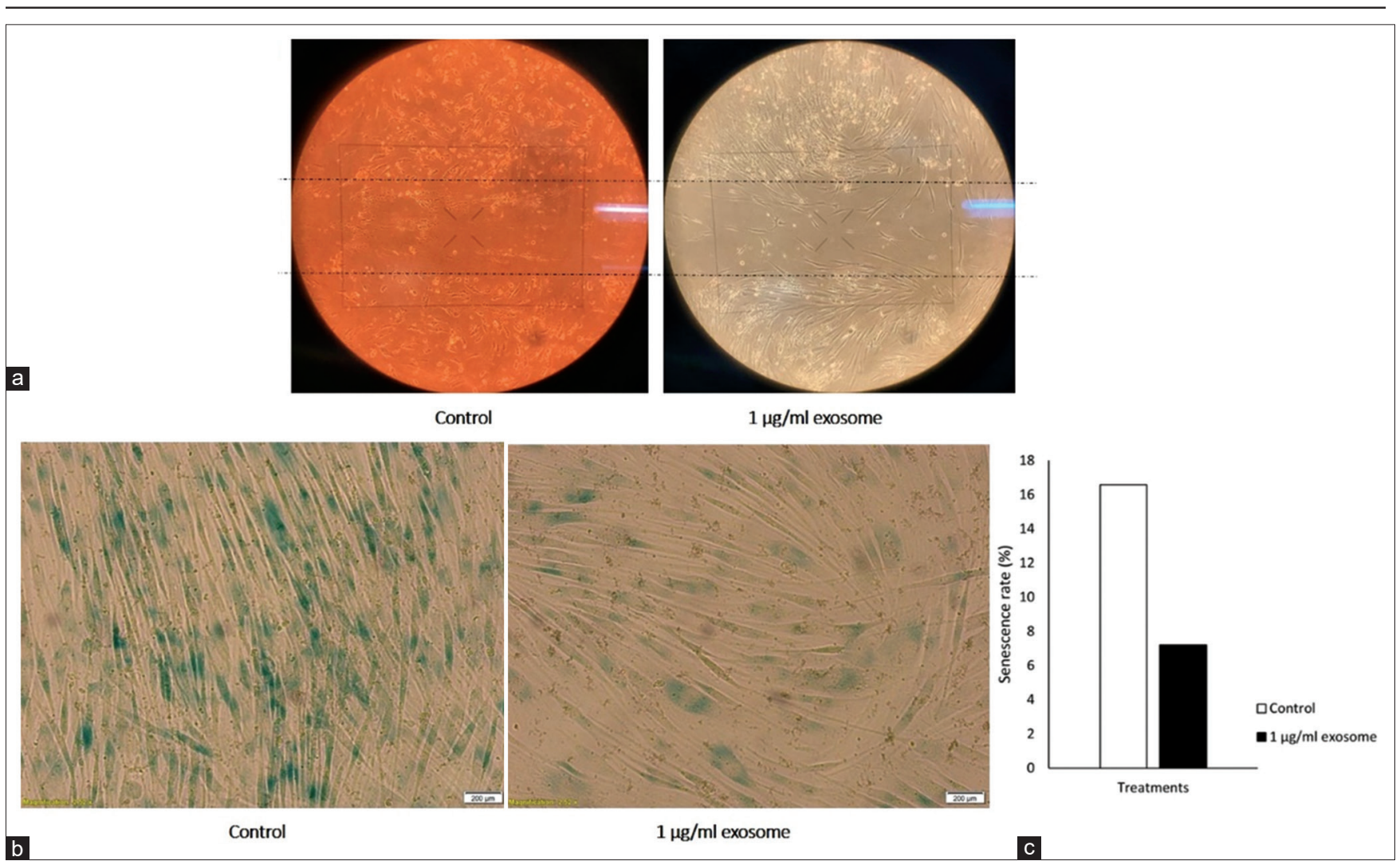

Figure 2: Adipose-derived stem cells derived exosomes promote migration and shift senescence human dermal fibroblast (HDFs) into normal.

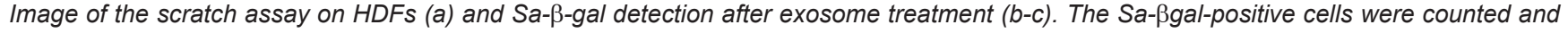
represented in figure $c$

Besides, we also evaluated FOXM1 protein expression in HDFs after exosome treatment. The results showed that the average of the control group and the exosome-treated group was $2.52 \pm 0.54$ and $4.13 \pm 0.93$, respectively, with $p<0.001$. The exosometreated group, in which the senescent HDFs were fewer than the control group, had elevated FOXM1 protein expression (Table 2).

Table 2: Independent t-test results of FoxM1 protein expression

\begin{tabular}{lll}
\hline Groups & Average $\pm \mathrm{SD}^{*}$ & $\mathrm{p}$-value \\
\hline Control group (untransfected) & $2.52 \pm 0.54$ & $<0.001$ \\
Exosome-treated group $(1 \mathrm{\mu g} / \mathrm{ml}$ exosome $)$ & $4.13 \pm 0.93$ & \\
\hline
\end{tabular}

Exosome-treated group $(1 \mathrm{\mu g} / \mathrm{ml}$ exosome $)$ *SD: Standard deviation

\section{Discussion}

A previous study addressed that ADSC-CM promotes collagen production and fibroblast movement [16]. The promotion is affected by the paracrine effect that helps ADSC and fibroblast to communicate [18] and repair damaged neighboring cells [16]. One of the communicators between cells is the exosome. It has been reported to stimulate the migration of fibroblast during wound healing process [22]. Similarly, our result proved that exosomes from ADSC-CM promoted the migration of HDFs.
Senescent HDFs have a morphological change, for example, the size of the cell is bigger, flat, and had a vacuole and many nuclei [23]. Some senescent markers that are usually used are Sa- $\beta$ gal enzyme detection, $\mathrm{p} 16^{\mathrm{INK} 4 \mathrm{~A}}, \mathrm{p} 53, \mathrm{p} 21^{\mathrm{CIP} 1}, \mathrm{Rb}$, and FOXM1 [24].

ADSCs have regenerative ability because they can secrete growth factors, differentiate, exhibit immunosuppressive ability, and promote homing to wound areas [19], [20]. Their mechanism might be caused by paracrine activity. The use of conditioned media to substitute the cells will avoid hypersecretion of growth factor, thus, it will minimize patients from getting the risk of paracrine effect [18], [20].

Senescence in HDFs happens when the cells are arrested from the cell cycle in the late G1 phase. This state can keep damaged cells from experiencing proliferation [25]. It has been reported that exosomes from ADSC-CM may shift this condition into normal because they work as pro-survival by triggering cell cycle in HDFs [26].

In the cell cycle system, $\mathrm{Rb}$ protein works together with p53. The disruption of their pathway leads to senescence, inhibition of cell cycle progression, and apoptosis. If their pathway is inactivated, cells will lose the antitumor mechanism and undergo proliferation. When the cells are in a senescence state, $\mathrm{Rb}$ protein and p53 expressions escalated [27]. It has been 
reported that exosomes from ADSC-CM can also stimulate the proliferation of fibroblasts [26]. In our finding, more than half of all senescent HDFs can be reverted into normal cells. This program seems to be encouraged by the exosome that reactivates $\mathrm{Rb}$ protein expression after the stress signal. Additional research to turn all senescent HDFs into normal is still needed.

The $\mathrm{Rb}$ might be suppressing FOXM1 by binding directly to its central domain and inhibits its transcription [28]. However, Cyclin D1-CDK4 phosphorylates $\mathrm{Rb}$. Therefore, $\mathrm{Rb}$ repression can be decreased and FOXM1 transcription at the G1/S phase increased [29], [30].

FOXM1 is only found in proliferative cells. During the cell cycle, the FOXM1 transcriptional activity is upregulated and congruent with its phosphorylation that is regularly altered. Hypophosphorylation of FOXM1 protein is controlled over the G1/S phase. From the $S$ phase to the G2/M phase transition, the phosphorylation elevated then it reaches the peak status in the M phase. In the late $\mathrm{M}$ phase, the protein will be dephosphorylated. Kinases and their positive feedback loops manage those processes [28]. We reported that FOXM1 protein expression was escalated by exosomes from ADSC-CM. The existence of FOXM1 induces other genes that support cell division at the G1/S phase and suppress senescent cells [31]. However, FOXM1 expression is downregulated in the senescent fibroblast [23].

\section{Conclusion}

It appears that the exosomes from ADSC-CM stimulate migration and reversal of senescent HDFs, and are mediated by the increased expression of Rb1 and FOXM1. The limitation of this study was about the donor of ADSC and HDF that were from one subject only. In the imminent future, further research should be allocated to unravel the processes by which exosomes promote Rb1 and FOXM1, thus exosomes can be developed as novel drugs targeting aging.

\section{Acknowledgments}

The authors would like to thank RSIA Melati Husada Malang, Indonesia, for providing the fat and dermal tissue. The authors have no conflicts of interest to declare. The authors would like to thank Dr. dr. Tinny Endang Hernowati, $\operatorname{SpPK}(\mathrm{K})$, for the kindness and support during the research, may she rest in peace.

\section{Authors' Contribution}

This study was carried out in collaboration between all authors. SM: Conceptualization, Data curation, formal analysis, investigation, methodology, writing - original draft, and writing - review and editing. LPA: Formal analysis, investigation, methodology, and writing - review and editing. SW: Formal analysis, investigation, supervision, and writing - review and editing. ATE: Formal analysis, supervision, and writing - review and editing. TWS: Formal analysis, funding acquisition, investigation, supervision, and writing - review and editing.

\section{References}

1. Behl C, Ziegler C. Cell cycle: The life cycle of a cell. In: Cell Aging: Molecular Mechanisms and Implications for Disease. New York: Springer; 2014. p. 9-19.

2. Bristow SL, Leman AR, Haase SB. Cell cycleregulated transcription: Effectively using a genomics toolbox. Methods Mol Biol. 2014;1170:3-27. https://doi. org/10.1007/978-1-4939-0888-2_1

PMid:24906306

3. Spoerri L, Oo ZY, Larsen JE, Haass NK, Gabrielli B, Pavey S. Cell cycle checkpoint and dna damage response defects as anticancer targets: From molecular mechanisms to therapeutic opportunities. In: Wondrak G, editor. Stress Response Pathways in Cancer. Dordrecht: Springer; 2015. https://doi. org/10.1007/978-94-017-9421-3_3

4. Bueno MJ, Malumbres M. MicroRNAs and the cell cycle. Biochim Biophys Acta. 2011;1812(5):592-601. https://doi. org/10.1016/j.bbadis.2011.02.002

PMid:21315819

5. Hindley C, Philpott A. The cell cycle and pluripotency. Biochem J. 2013;451(2):135-43. https://doi.org/10.1042/BJ20121627 PMid:23535166

6. Mens MM, Ghanbari M. Cell cycle regulation of stem cells by MicroRNAs. Stem Cell Rev. 2018;14(3):309-22. https://doi. org/10.1007/s12015-018-9808-y PMid:29541978

7. Litovchick L, Sadasivam S, Florens L, Zhu X, Swanson SK Velmurugan $\mathrm{S}$, et al. Evolutionarily conserved multisubunit RBL2/ p130 and E2F4 protein complex represses human cell cycledependent genes in quiescence. Mol Cell. 2007;26(4):539-51. https://doi.org/10.1016/j.molcel.2007.04.015

PMid: 17531812

8. Grant GD, Brooks L, Zhang X, Mahoney JM, Martyanov V, Wood TA, et al. Identification of cell cycle-regulated genes periodically expressed in U2OS cells and their regulation by FOXM1 and E2F transcription factors. Moll Biol Cell. 2013;24(23):3634-50. https://doi.org/10.1091/mbc.e13-05-0264 PMid:24109597

9. Beishline K, Azizkhan-Clifford J. Interplay between the cell cycle and double-strand break response in mammalian cells. Methods Mol Biol. 2014;1170:41-59. https://doi. org/10.1007/978-1-4939-0888-2_3

PMid:24906308 
10. Zona S, Bella L, Burton MJ, de Moraes GN, Lam EW. FOXM1: An emerging master regulator of DNA damage response and genotoxic agent resistance. Biochim Biophys Acta. 2014;1839(11):1316-22. https://doi.org/10.1016/j. bbagrm.2014.09.016 PMid:25287128

11. Kalin TV, Ustiyan V, Kalinichenko VV. Multiple faces of FoxM1 transcription factor: Lessons from transgenic mouse models. Cell Cycle. 2011;10(3):396-405. https://doi.org/10.4161/ cc.10.3.14709

PMid:21270518

12. Lim S, Kaldis P. Cdks, cyclins and CKIs: Roles beyond cell cycle regulation. Development. 2013;140(15):3079-93. https://doi. org/10.1242/dev.091744

PMid:23861057

13. Koo C, Muir KW, Lam EW. FOXM1: From cancer initiation to progression and treatment. Biochim Biophys Acta. 2012;1819(1):28-37. https://doi.org/10.1016/j. bbagrm.2011.09.004 PMid:21978825

14. Herranz N, Gil J. Mechanisms and functions of cellular senescence. J Clin Invest. 2018;128(4):1238-46. https://doi. org/10.1172/JCl95148

PMid:29608137

15. Sikora E. Rejuvenation of senescent cells-the road to postponing human aging and age-related disease? Exp Gerontol. 2013;48(7):661-6. https://doi.org/10.1016/j.exger.2012.09.008 PMid:23064316

16. van Deursen JM. The role of senescent cells in ageing. Nature. 2014;509(7501):439-46. https://doi.org/10.1038/nature13193 PMid:24848057

17. Song SY, Jung JE, Jeon YR, Tark KC, Lew DH. Determination of adipose-derived stem cell application on photo-aged fibroblasts, based on paracrine function. Cytotherapy. 2011;13(3):378-84. PMid:21062113

18. Kokai LE, Marra KG, Rubin JP. Adipose stem cells: Biology and clinical applications for tissue repair and regeneration. Transl Res. 2014;163(4):399-408. https://doi.org/10.1016/j.trsl.2013.11.009 PMid:24361334

19. Hur W, Lee HY, Min HS, Wufuer M, Lee C, Hur JA, et al. Regeneration of full-thickness skin defects by differentiated adipose-derived stem cells into fibroblast-like cells by fibroblastconditioned medium. Stem Cell Res Ther. 2017;8(1):92. https:// doi.org/10.1186/s13287-017-0520-7 PMid:28427476

20. Shan X, Roberts C, Kim EJ, Brenner A, Grant G, Percec I. Transcriptional and cell cycle alterations mark aging of primary human adipose-derived stem cells. Stem Cells. 2017;35(5):1392-401. https://doi.org/10.1002/stem.2592 PMid:28211118

21. Zhang J, Guan J, Niu X, Hu G, Guo S, Li Q, et al. Exosomes released from human induces pluripotent stem cells-derived MSCs facilitate cutaneous wound healing by promoting collagen synthesis and angiogenesis. J Transl Med. 2015;13:49. https:// doi.org/10.1186/s12967-015-0417-0

PMid:25638205

22. Raik S, Kumar A, Bhattacharyya S. Insights into cell-free therapeutic approach: Role of stem cell soup-ernatant. Biotechnol Appl Biochem. 2018;65(2):104-18. https://doi. org/10.1002/bab.1561

PMid:28321921

23. Oh M, Lee J, Kim YJ, Rhee WJ, Park JH. Exosomes derived from human induced pluripotent stem cells ameliorate the aging of skin fibroblasts. Int J Mol Sci. 2018;19(6):1715. https://doi. org/10.3390/ijms19061715

PMid:29890746

24. Schäuble S, Klement K, Marthandan S, Münch S, Heiland I, Schuster $S$, et al. Quantitative model of cell cycle arrest and cellular senescence in primary human fibroblasts. PLoS One. 2013;7(8):e42150. https://doi.org/10.1371/journal. pone.0042150

PMid:22879912

25. Takahashi A. A novel mechanism of irreversible cell cycle arrest in cellular senescence. J Oral Biosci. 2007;49(1):47-53. https:// doi.org/10.1016/S1349-0079(07)80015-6

26. Choi EW, Seo MK, Woo EY, Kim SH, Park EJ, Kim S. Exosomes from human adipose-derived stem cells promote proliferation and migration of skin fibroblasts. Exp Dermatol. 2018;27(10):1170-2. https://doi.org/10.1111/exd.13451 PMid:28940813

27. Zhu L, Lu Z, Zhao H. Antitumor mechanisms when $\mathrm{pRb}$ and $\mathrm{p} 53$ are genetically inactivated. Oncogene. 2015;34(35):4547-57. https://doi.org/10.1038/onc.2014.399 PMid:25486431

28. Liao G, Li X, Zeng S, Liu C, Yang S, Yang L, et al. Regulation of the master regulator FOXM1 in cancer. Cell Commun Signal. 2018;16:57. https://doi.org/10.1186/s12964-018-0266-6 PMid:30208972

29. Halasi M, Gartel AL. FOX(M1) news--it is cancer. Mol Cancer Ther. 2013;12(3):245-54. https://doi.org/10.1158/1535-7163. mct-12-0712

PMid:23443798

30. Kelleher FC, O'Sullivan H. FOXM1 in sarcoma: Role in cell cycle, pluripotency genes and stem cell pathways. Oncotarget. 2016;7(27):42792-804. https://doi.org/10.18632/ oncotarget.8669

PMid:27074562

31. Xu H, Yu S, Liu Q, Yuan X, Mani S, Pestell RG, et al. Recent advances of highly selective CDK4/6 inhibitors in breast cancer. J Hematol Oncol. 2017;10(1):97. https://doi.org/10.1186/ s13045-017-0467-2

PMid:28438180 